\title{
Large-scale englacial folding and deep-ice stratigraphy within the West Antarctic Ice Sheet
}

\author{
Neil Ross ${ }^{1}$, Hugh Corr $^{2}$, and Martin Siegert ${ }^{3}$ \\ ${ }^{1}$ School of Geography, Politics and Sociology, Newcastle University, Newcastle upon Tyne, UK \\ ${ }^{2}$ British Antarctic Survey, High Cross, Cambridge, UK \\ ${ }^{3}$ Grantham Institute and Department of Earth Science and Engineering, Imperial College London, London, UK
}

Correspondence: Neil Ross (neil.ross@newcastle.ac.uk)

Received: 15 October 2019 - Discussion started: 7 November 2019

Revised: 4 May 2020 - Accepted: 18 May 2020 - Published: 30 June 2020

\begin{abstract}
It has been hypothesized that complex englacial structures identified within the East Antarctic and Greenland ice sheets are generated by (i) water freezing to the ice sheet base and evolving under ice flow, (ii) deformation of ice of varying rheology, or (iii) entrainment of basal material. Using ice-penetrating radar, we identify a widespread complex of deep-ice facies in West Antarctica that exist in the absence of basal water. These deep-ice units are extensive, thick ( > $500 \mathrm{~m}$ ), and incorporate multiple highly reflective englacial layers. At the lateral margin of an enhanced flow tributary of the Institute Ice Stream, these units are heavily deformed and folded by the action of lateral flow convergence. Radar reflectivity analysis demonstrates that the uppermost reflector of the deep-ice package is highly anisotropic, due to abrupt alternations in crystal orientation fabric, and consequently will have a different rheology to the ice above and below it. Deformation and folding of the deep-ice package is an englacial response to the combination of laterally-convergent ice flow and the physical properties of the ice column.
\end{abstract}

\section{Introduction}

Recent advances in radar technology have enhanced the quality and resolution of ice-penetrating radar data, revealing complex structures in the lower ice sheet column. Thick deep-ice units have been imaged above the Gamburtsev Mountains in East Antarctica (Bell et al., 2011; Wrona et al., 2018), whilst in Greenland units heavily deformed by ice flow have been discovered (NEEM community members, 2013; Bell et al., 2014; Bons et al., 2016). These have been interpreted as the product of the accretion of basal water (Bell et al., 2011), deformation caused by varying rheology of the ice column (NEEM community members, 2013; Bons et al., 2016), or a combination of both (Bell et al., 2014; Wrona et al., 2018). Only a few studies (e.g. Wolovick et al., 2014, 2016; Leysinger Vieli et al., 2018) have assessed the impact of such units on ice sheet flow and dynamics, and there are only limited reports of the existence of thick deformed deepice units in West Antarctica (Jacobel et al., 1993; Siegert et al., 2004). Englacial seismic boundaries in deep ice across the West Antarctic Ice Sheet have been reported (Bentley, 1971; Horgan et al., 2011). Once interpreted as sediments within the ice (Bentley, 1971), it is now understood that these reflections represent a shift in the orientation of the ice crystal fabric (Gow and Williamson, 1976; Horgan et al., 2011; Robin and Millar, 1982). However, the spatial extent and significance of such fabrics in West Antarctica (and deep-ice units in general) have not been determined.

Here, we present ice-penetrating radar data revealing an extensive package of deep-ice facies locally characterized by a zone of large-scale folding at the lateral margin of a tributary of convergent enhanced (i.e. $>25 \mathrm{~m} \mathrm{a}^{-1}$ ) ice flow (Joughin et al., 1999; Bamber et al., 2000). Like a structural geology problem (MacGregor et al., 2015; Hudleston, 2015), such folds can only be explained by the deformation of ice with contrasting physical properties near the base of the ice sheet. Evidence of variability in physical properties is consistent with ice-penetrating radar observations of a widespread englacial layer characterized by strongly anisotropic ice crystal fabric, as postulated for ice folds in Greenland (Bons et al., 2016). 


\section{Methods}

Airborne $150 \mathrm{MHz}$ ice-penetrating radar data were acquired over the Institute and Möller ice streams (IIS, MIS) of West Antarctica in 2010/2011 (Ross et al., 2012; Jeofry et al., 2018a; Ashmore et al., 2020). Coverage extended from the ice stream grounding zone to the ice divide (Fig. 1a). A highresolution grid with an across-ice flow line spacing of $7.5 \mathrm{~km}$ and tie lines at $25 \mathrm{~km}$ spacing was acquired over the central parts of the ice stream catchments.

Data acquisition and processing and analysis of the radar data are described fully by Jeofry et al. (2018a) and briefly summarized here. The range from the aircraft to the ice surface was determined using the aircraft radar altimeter or lidar measurements. Ice thickness was determined by multiplying the two-way travel time between the picked ice surface and the picked reflection from the ice sheet bed by $0.168 \mathrm{~m} \mathrm{~ns}^{-1}$ and applying a $10 \mathrm{~m}$ correction for the firn layer (Jeofry et al., 2018a). Bed elevation was calculated by subtracting ice thickness from ice surface elevation. Internal ice sheet layering, and the determination of fold axis positions, were visualized and manually picked using geophysical software, and 2D synthetic-aperture radar (SAR)-processed radargrams are displayed with a natural logarithm applied to enhance reflections at depth. The data used were from the chirp mode of the PASIN system (Jeofry et al., 2018a; Ashmore et al., 2020). We did not use PASIN pulse channel data in this study.

Analysis of the returned radar power of internal reflectors at flight line crossover points was implemented to evaluate possible anisotropy within the ice column. This was possible due to the stepped nature of the aerogeophysical survey (i.e. most of the survey was flown in a series of blocks of constant aircraft elevation), which was implemented for acquisition of high-quality gravity data (Jordan et al., 2013), meaning that aircraft-to-ice surface range was consistent between flight lines at many crossover locations. At those crossover points where the aircraft-to-surface range was the same in perpendicular survey lines, we stacked radar traces over 41 traces $(\sim 400 \mathrm{~m}$ along track) and determined the returned integrated power down ice, between samples 200 and 1400 (two-way travel time of $54545 \mathrm{~ns}$ ) in the across- and alongice flow directions.

Though the survey grid design allows us to undertake a detailed analysis of the pseudo-3D englacial structure of the IIS, the grid layout and orientation of the 2D survey flights was not aligned exactly along and across the ice flow. This oblique offset can have implications for the 2D imaging of 3D englacial structures (Bingham et al., 2015). In general, however, our survey grid is approximately aligned along and across flow throughout most of our area of interest. As a result, we refer from this point onwards to "across-flow" and "along-flow" flight lines, although we acknowledge that in many places the flight lines are slightly oblique to both the along- and across-ice flow vectors.

\section{Observations}

\subsection{Ice sheet stratigraphy and physical properties}

The radar data reveal an extensive deep-ice unit with a distinctive ice sheet stratigraphy across an area $>250000 \mathrm{~km}^{2}$ (Fig. 1b). The unit extends from the Ellsworth Subglacial Highlands (Ross et al., 2014; Winter et al., 2015; Goldberg et al., 2020) to a region of thin cold-based ice between the MIS and Foundation Ice Stream (Bingham et al., 2015) and from the ice stream trunk (Siegert et al., 2016) to near the Weddell-Ross ice divide (Fig. 1a-b). The stratigraphy of the ice sheet column is comprised of a high-reflectivity upper unit, typically $750-1500 \mathrm{~m}$ in thickness, with thinly-stratified minimally-disrupted layering, typical of meteoric ice, overlying a low-reflectivity lower-ice column up to $\sim 1000 \mathrm{~m}$ thick (Fig. 2). The boundary between these two stratigraphic units is often sharp and associated with either a distinctive thick (up to $200 \mathrm{~m}$ ) band of high-reflectivity (R1) or a marked reduction in returned radio wave energy, depending on radar instrument orientation (Figs. 3 and 6). Beneath R1, within the low-reflectivity lower-ice column, a second highly reflective englacial reflection (R2) is observed. R2 sometimes diverges and bifurcates, becoming a series of 3-4 layers (Fig. 2b). Here, for simplicity, we refer to R2 as a single "reflection package". Between R1 and R2, a series of very thin and very low-reflectivity reflections can be imaged, but below R2 (i.e. between it and the bed) layering is typically absent except for occasional, localized, near-bed reflections (Fig. 2c).

The deep-ice unit is extensively folded (Figs. 3 and 4) at the lateral boundary of an enhanced flow tributary (Fig. 1c) that feeds the IIS (Figs. 1b-c, 2a). The geometry and structure of the deep-ice unit that includes R1 and R2 differs markedly in three dimensions in this area. Radar data orthogonal to ice flow (Figs. 3a and 4) show substantially folded layering (with amplitudes of up to $40 \%$ of the ice column in places), with clear evidence of a series of bed-unconformable anticlines and synclines (Figs. 3a, 3b, 4). Along-ice flow, however, the same unit is characterized by more subdued reflections, with bed-conformable undulations rather than folds (Figs. 2b-c, 3c and 4). The deep-ice folds we observe are comparable in scale to those within the onset zone and trunk of Petermann Glacier in Greenland (Bons et al., 2016), rather than the higher-frequency, lower-amplitude buckling often associated with enhanced ice flow (Conway et al., 2002; Ng and Conway, 2004).

The structure of the upper part of the ice sheet is highly affected by the presence and folding of the deep-ice unit below R1 and shows evidence of higher-frequency folding. The upper ice column is disrupted by "whirlwind" or "tornado" features (Karlsson et al., 2009; Winter et al., 2015) caused by radar energy dispersion through focused SAR processing of sloping and buckled layers in airborne radar data (Holschuh et al., 2014) (Fig. 3a and b). Whirlwinds have been identified as a signature of either structural disruption of the ice 

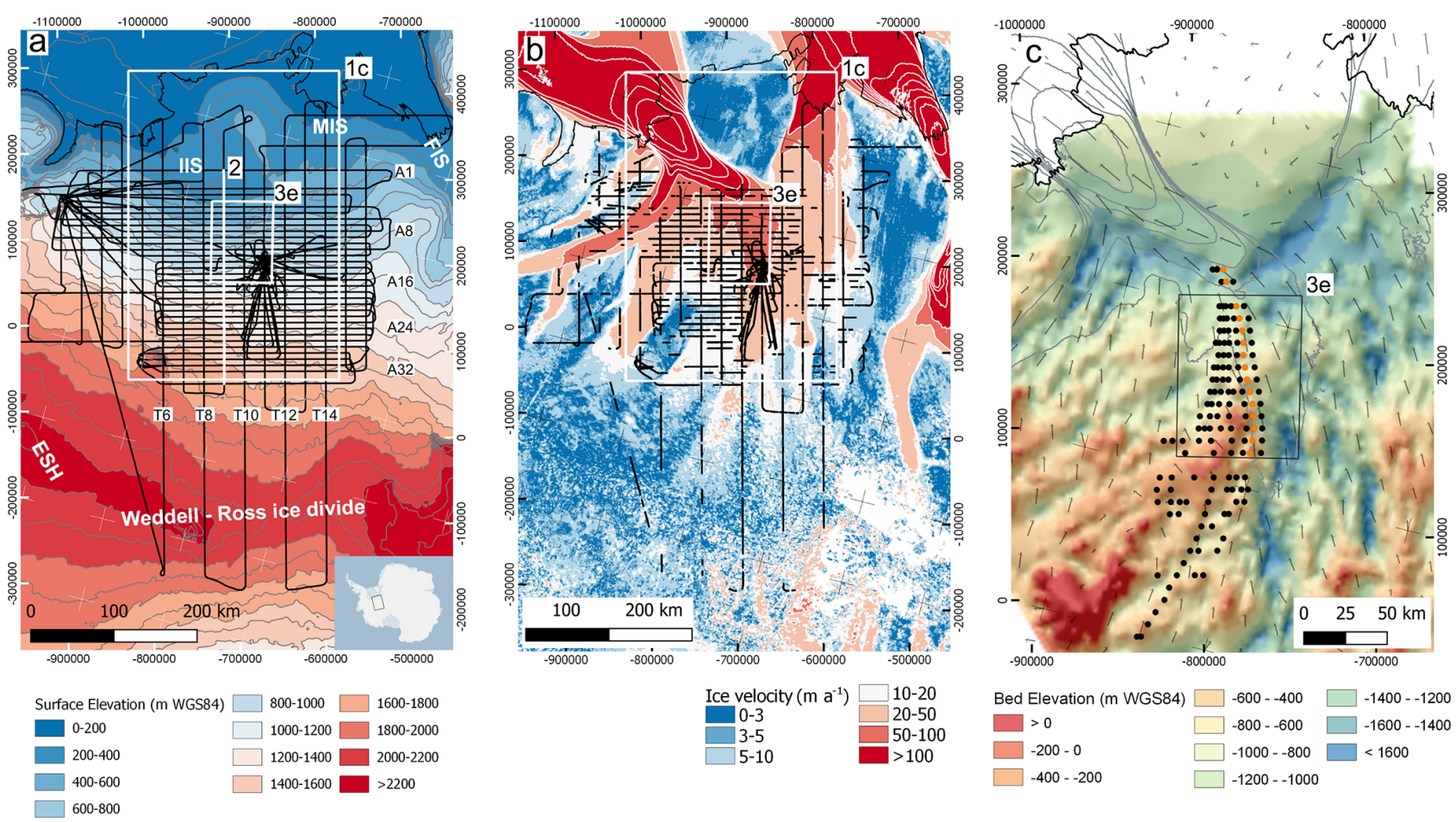

Figure 1. (a) Ice-penetrating radar survey flights over the catchments of the Institute and Möller ice streams (thick black lines), overlain on ice surface elevation (m WGS84) (Bamber et al., 2009). The thin black line in all panels is the MODIS grounding line (Bohlander and Scambos, 2007). The grey lines are ice surface elevation contours at $100 \mathrm{~m}$ intervals. The Möller Ice Stream (MIS), Institute Ice Stream (IIS), Foundation Ice Stream (FIS), Weddell-Ross ice divide, and Ellsworth Subglacial Highlands (ESH) are indicated. The white boxes indicate extents of (c) and Fig. 3e. The white line is survey tie line 9, shown in Fig. 2. The inset in (a) shows the Antarctic location of (a)-(b). (b) Observations of deep-ice unit R1 in radargrams across the study area (thick black lines) overlain on MEASURES ice velocity (Rignot et al., 2017). The white lines are velocity contours at $50 \mathrm{~m} \mathrm{a}^{-1}$ intervals. Gaps in observations are either where data were not acquired or where the deep-ice unit could not be identified in the radar data (e.g. because of signal attenuation). The white boxes indicate extents of (c) and Fig. 3e. (c) Folded deep ice beneath IIS, relative to basal topography (Ross et al., 2012) and surface ice flow (Rignot et al., 2017). The location of fold axis peaks, identified in radargrams, are represented by black and orange circles, the latter colour denoting the position of the fold with the "hand-shaped" reflection (Fig. 3d) at its core. The black box defines the limits of Fig. 3e. The thin grey lines are $50 \mathrm{~m}$ contours of MEASURES ice velocity (Rignot et al., 2017). The arrows show the direction and magnitude of the ice flow (Rignot et al., 2017).

by enhanced flow or slow ice flow over rugged basal topography. In our data, whirlwinds tend to be vertical to subvertical throughout the majority of the ice column but display a prominent deviation from the vertical (i.e. they bend) at depth, specifically in the low-reflectivity unit between R1 and R2 (Fig. 3a and b). The whirlwinds approach and show the greatest deviation towards $\mathrm{R} 2$, yet never cross this reflection boundary (Fig. 3a and b). Due to their 3D geometry, whirlwinds are visible in data acquired perpendicular and sub- perpendicular to the ice flow but not in radar data acquired parallel to it (Fig. 3) (Bingham et al., 2015).

\subsubsection{Relationship between englacial folding and ice flow}

A close spatial coincidence exists between the deep-ice folds and the onset of enhanced $\left(\sim 25 \mathrm{~m} \mathrm{a}^{-1}\right)$ flow in the IIS catchment (Fig. 1c). Five anticlines and synclines with a wavelength of $3-5 \mathrm{~km}$ are directly associated with the lateral boundary of an enhanced flow tributary of IIS (Bamber et al., 2000). These folds have axes oriented precisely along flow and are mappable in more than 20 across-ice-flow flight lines over a distance of $\sim 150 \mathrm{~km}$ (Figs. 1c and 4). Due to lateral ice flow convergence, the amplitude and wavelength of the folds associated with the shear zone increase and decrease, respectively, down the ice flow. The folds become harder to identify in our data in the main trunk of the IIS due to high ice velocities $\left(>150 \mathrm{~m} \mathrm{a}^{-1}\right)$, associated strain rates, and bright basal reflections (Figs. 1c and 5). The folds are highly nonbed-conformable, despite the bed topography being notably flat (Rose et al., 2015) or characterized by long-wavelength topographic variation (Fig. $3 a$ and $b$ ).

\subsection{Down-ice propagation and glaciological implications of the englacial folds}

Though eventually the englacial radar reflection signature of the folds is significantly modified by highly convergent fast 

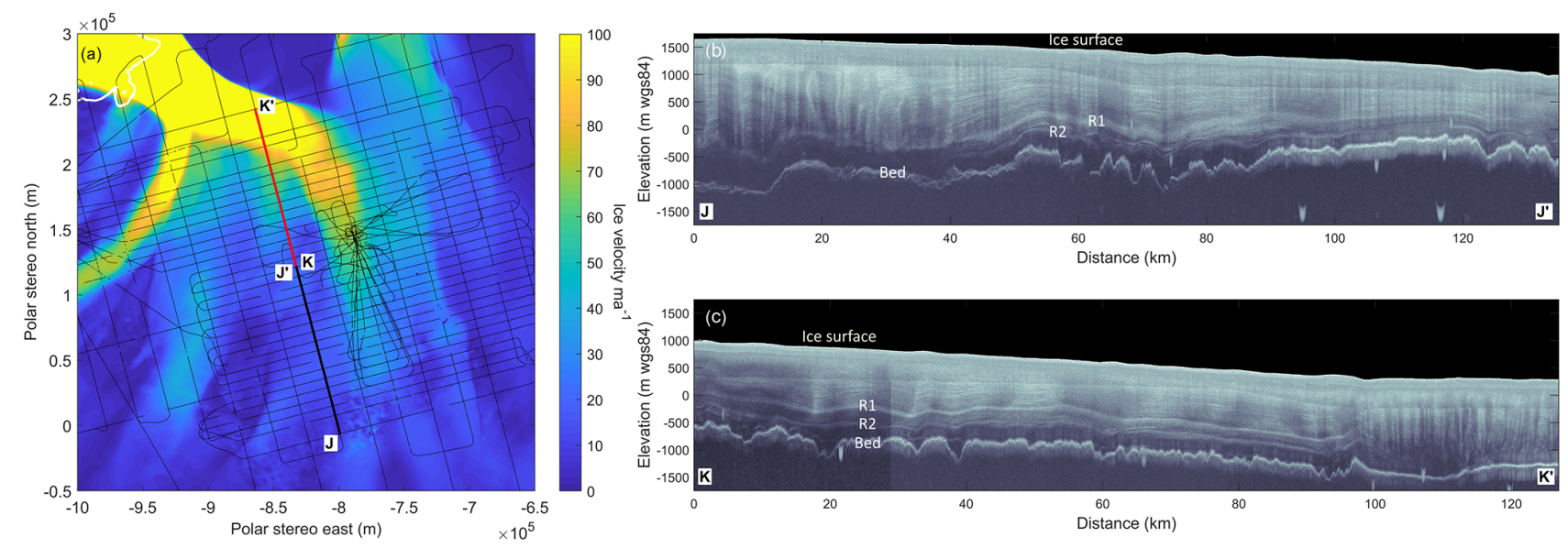

Figure 2. A total of $260 \mathrm{~km}$ of radar data along tie line 9 demonstrating the typical stratigraphy of the ice column (high-reflectivity meteoric ice, underlain by low-reflectivity lower ice column with high-reflectivity layers) and the brightness and widespread nature of the band of ice layers (R1 and R2) throughout the IIS and MIS catchments: (a) map of ice velocity (Mouginot et al., 2019) with the IMAFI survey grid (thin black lines), grounding line (white line), and location of radar data in (b) (thick black line) and (c) (thick red line). The ice velocity colour scale is saturated at $100 \mathrm{ma}^{-1}$. (b) Radargram of the upper to middle IIS catchment (thick black line in a). Note the bifurcation of R2 into 3-4 layers between 50-80 km. (c) Continuation of the radargram shown in (b) into the middle to lower IIS catchment (thick red line in a). Radargrams in (b) and (c) are radar survey tie line 9, which is also shown in Figs. 4 and S1. Isolated U-shaped "blobs" are artefacts associated with SAR processing of the radar data.

flow in the IIS trunk, mapping of the fold axes combined with surface observations from RADARSAT and MODIS (Fig. 5) demonstrates an association between the most prominent fold (Fig. 3d) and a well-defined surface flow stripe (Fig. 5a) (Glasser and Gudmundsson, 2012; Ely and Clark, 2016) that extends from the onset zone where ice is typically flowing at $50-125 \mathrm{~m} \mathrm{a}^{-1}$, into the trunk, through the ice stream grounding zone, and onto the Ronne Ice Shelf (Fig. 5b). Radar data oriented obliquely to the ice flow direction (Fig. 5c and d) demonstrate that this fold and the surface flow stripe are associated with a significant shift in basal reflectivity (Siegert et al., 2016), suggesting that glaciological processes in the onset zone of IIS, of which the fold is a product, are likely to play an important role, alongside in situ subglacial topography and geology, in determining the compartmentalization and nature of ice flow within the IIS trunk (see Siegert et al., 2016; Jeofry et al., 2018b). The IIS trunk is divided into at least two flow compartments that relate to upstream tributary flow (Fig. 5a and b), with crevasse patterns on the surface of the ice stream trunk either side of the flow stripe evidencing very different strain regimes (Fig. 5a). We also observe that the surface feature above the englacial fold coincides with the grid-southwest margin of the ice plain at the IIS grounding zone (Fricker and Padman, 2006). The fold may therefore play a role in buttressing the IIS by influencing the position and form of the ice plain.

\subsection{Returned power of englacial layers}

$\mathrm{R} 1$ is often characterized by pronounced anisotropic reflections throughout the survey area. To demonstrate this anisotropy, we investigated the returned power of R1 in and around the broad enhanced flow tributary of the IIS (Fig. 6b). At survey crossover points within a $127.5 \mathrm{~km} \times 75 \mathrm{~km}$ zone, R1 often displays clear anisotropy, with much stronger (typically $10 \mathrm{~dB}$ or more) returned radar power in the along-iceflow direction than in radar survey data acquired across-iceflow (Fig. 6 and Supplement Figs. S1-S4). This anisotropy is similar in magnitude to that observed in East Antarctica as the ice flows over large subglacial obstacles (Fujita et al., 1999; Siegert and Fujita, 2001; Wang et al., 2018); the explanation being that enhanced stresses on the stoss face of basal hills lead to exaggerated strain in specific "soft" layers (of glacial as opposed to interglacial age).

\section{Discussion}

\subsection{Physical explanations for englacial reflections}

There are several possible explanations for the reflectivity of R1 and R2 including (i) constructive interference from a series of multiple thin layers (Harrison, 1973; Siegert, 1999), (ii) preferred ice crystal orientation fabrics (corresponding to power anisotropy for a specific radar layer) (e.g. Matsuoka et al., 2004; Eisen et al., 2007), (iii) birefringent propagation (corresponding to power oscillations as a function of ice depth) (Fujita et al., 2006), and (iv) an abrupt spike in the conductivity of the ice column associated with the deposition of volcanic ash (Paren and Robin, 1975; Corr and Vaughan, 2008). However, these explanations are not mutually exclusive, and it may be that more than one may act in combina- 

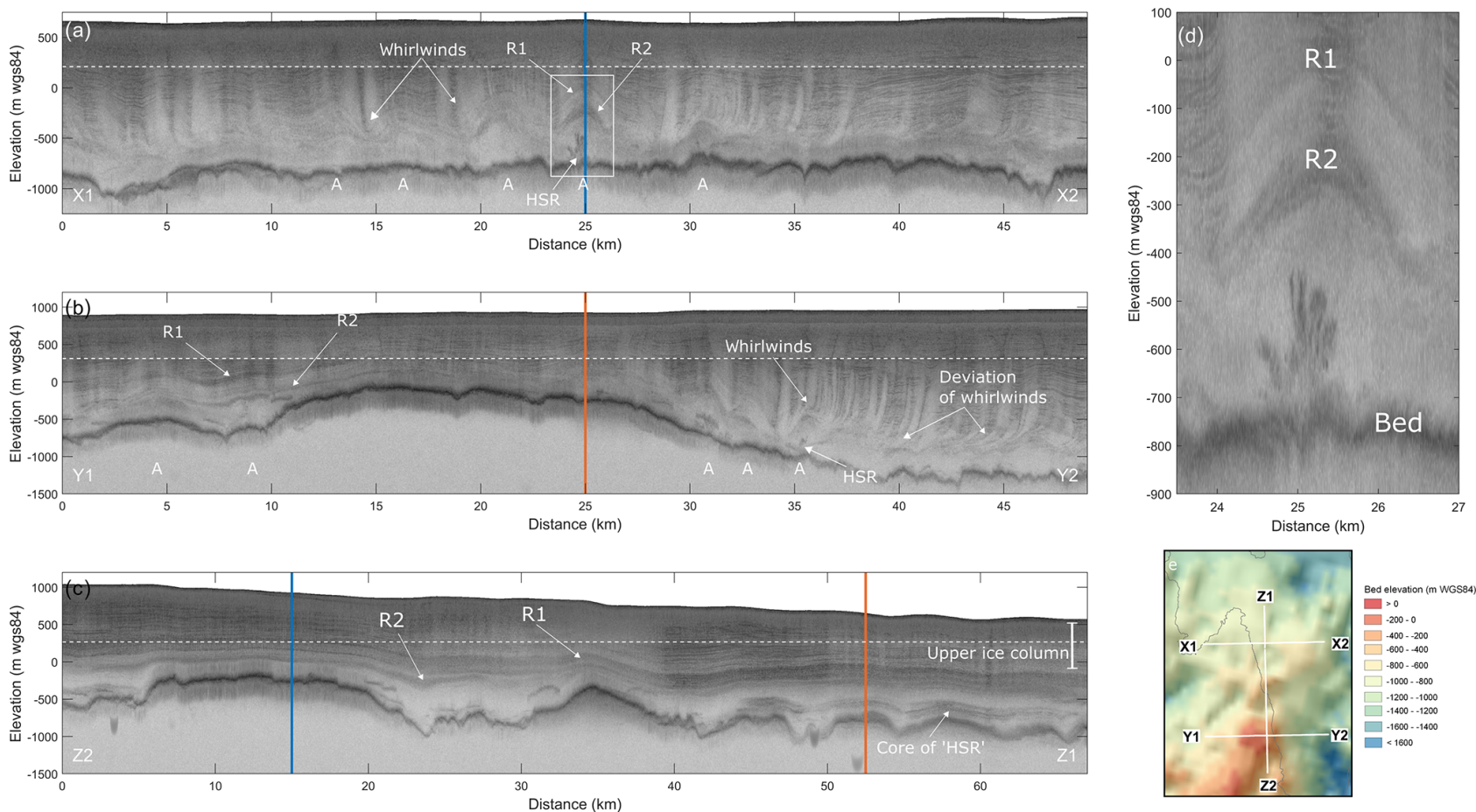

Figure 3. Ice-penetrating radargrams showing detailed englacial layering and folding: (a) across-flow radargram (X1-X2), with englacial folds and hand-shaped reflection (HSR); the view is in the down-ice direction; an intersection with along-flow radargram Z1-Z2 is indicated by the blue vertical line. The positions of fold anticlines are indicated with "A". The white box is the location of (d). (b) Across-flow radargram (Y1-Y2), showing early development of englacial folds and their positions (A); an intersection with along-flow radargram Z1-Z2 is indicated by the red vertical line. (c) Down ice-flow radargram (Z1-Z2) connecting (a) and (b). Ice flow is approximately left to right. Deep-ice units R1 and R2 are annotated. Intersections with radargrams X1-X2 and Y1-Y2 are indicated by blue and red vertical lines, respectively. (d) Zoom-in of the hand-shaped reflection from (a). (e) Map of subglacial topography (Ross et al., 2012) showing positions (white lines) of radar transects X1-X2, Y1-Y2, and Z1-Z2. The thin grey line is the $50 \mathrm{~m} \mathrm{a}^{-1}$ velocity contour (Rignot et al., 2017). Note that (a) has a different $y$ axis scale to (b) and (c).
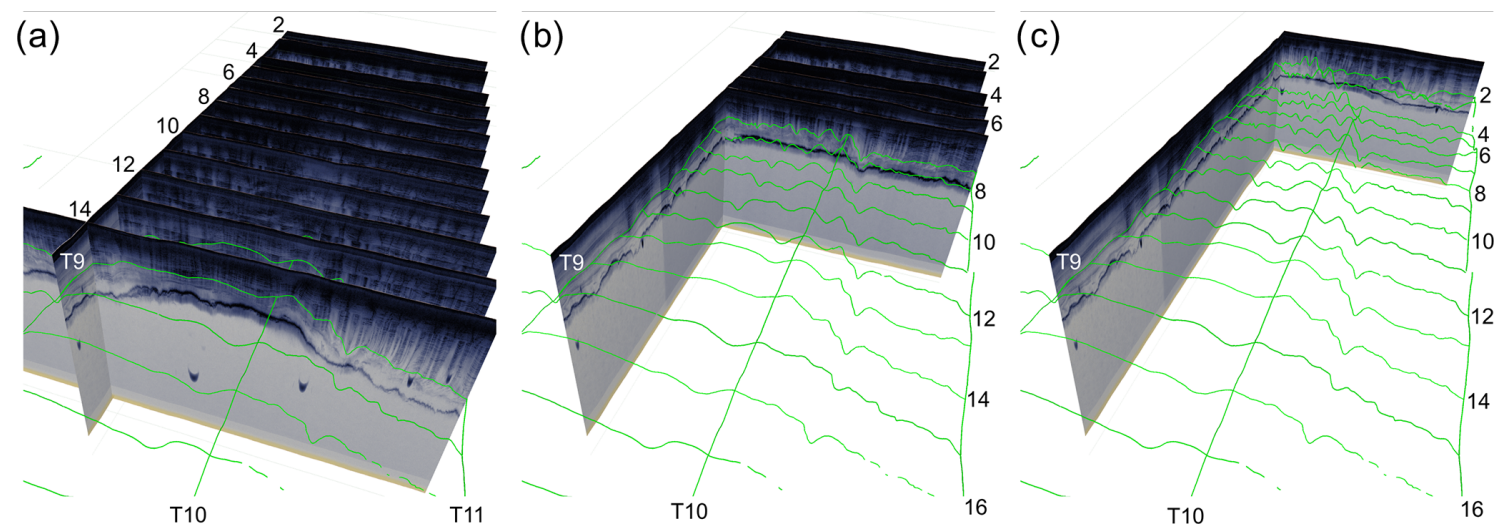

Figure 4. A 3D visualization of the picked (green lines) englacial layer R1, demonstrating the 3D pattern of folding and density of survey lines: (a) radargrams of across-ice-flow lines 14-2; (b) radargrams of across-ice-flow lines 7-2; (c) radargram of across-ice-flow line 2. Ice flow is into the page, and there is $105 \mathrm{~km}$ between across-flow lines 14 and 2 . The long down-ice tie line radargram shown in (a)-(c) is tie line 9 (Fig. 2c). Tie lines 9, 10, and 11 are annotated. 

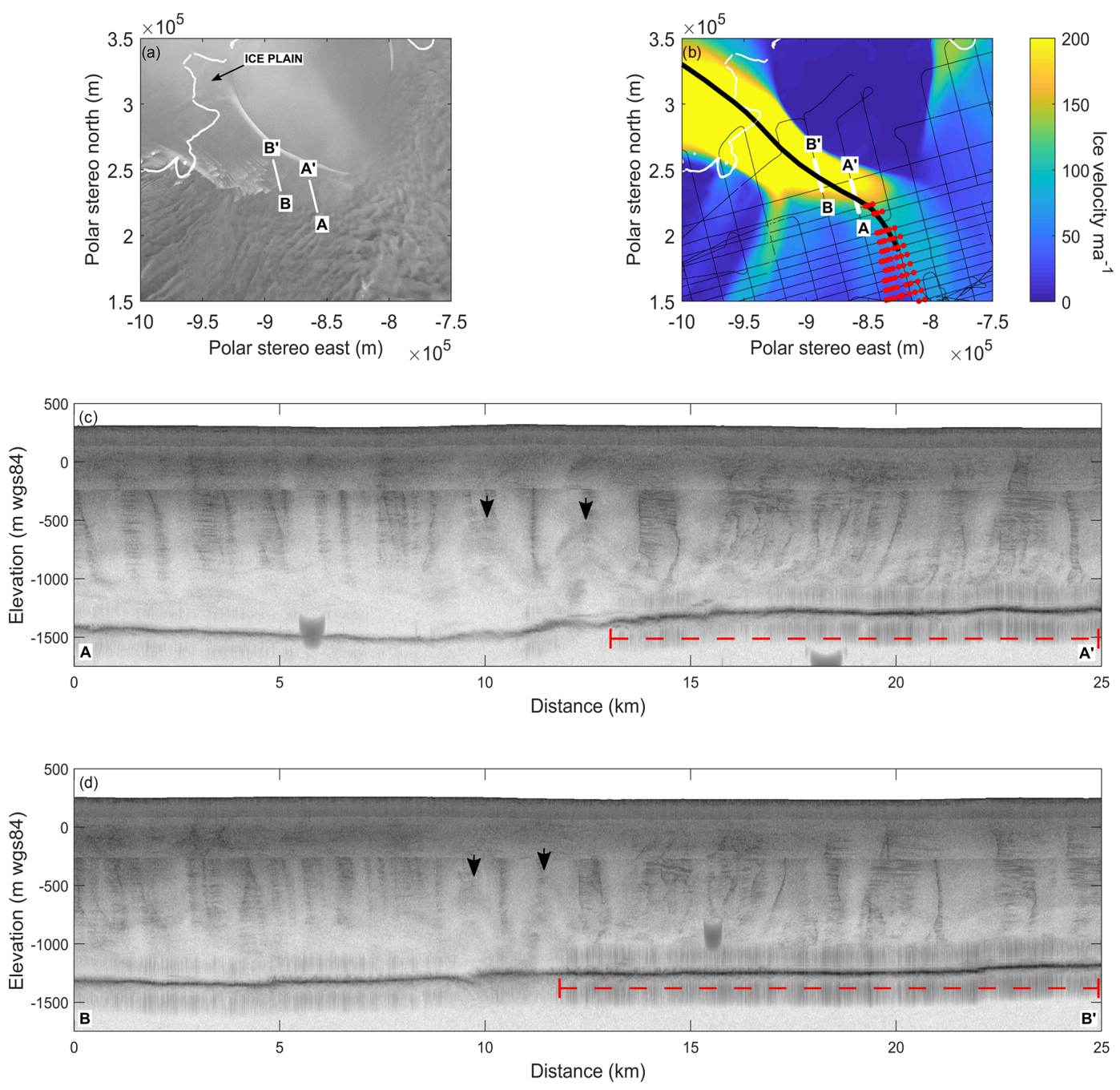

Figure 5. Englacial folds and ice flow of the IIS trunk: (a) RADARSAT image mosaic (Jezek et al., 2013) of the ice sheet surface of the IIS. Thick white lines show the positions of radar data shown in (c) and (d). The thin white line is the grounding line (Rignot et al., 2011). The ice plain of the IIS is annotated. (b) Mapped englacial fold axes (red dots) and a prominent surface flow stripe (thick black line) mapped using RADARSAT and MODIS mosaics of Antarctica (Jezek et al., 2013; Haran et al., 2005), overlain on ice flow (Mouginot et al., 2019), the IMAFI survey grid (thin black lines), and the grounding line (thin white line) (Rignot et al., 2011). (c, d) Radar data across the IIS trunk oblique to the flow stripe and ice flow, showing the subtle signature of the most apparent englacial folding (two black arrows) within the faster-flowing trunk. The hand-shaped-reflection (HSR) fold is the fold indicated by the right of the two black arrows. A qualitative increase in basal reflectivity is apparent to the right of the HSR fold in both radargrams (indicated by the dashed red line).

tion. However, because we observe that the strength of the returned energy from R1 is highly anisotropic, with higher reflectivity in the along-flow orientation (Figs. 2, 3, 4, 6, and S1-S4), we conclude that R1 is most likely caused by (ii) or (iii) (Fujita et al., 1999; Wang et al., 2018). The depth of R1 certainly rules out ice density fluctuations. In general, it is difficult to separate out (ii) and (iii). However, for the case of $\mathrm{R} 1$, we can assume that anisotropic scattering is the dominant cause of power anisotropy (the along- and across-flow profiles have similar long-wavelength behaviour, and the power anisotropy is localized for a set of radar layers). We therefore attribute R1 to crystal orientation fabric.
Radar reflection anisotropy associated with crystal orientation fabric has been verified by ice core evidence from Antarctica and Greenland (Eisen et al., 2007, Drews et al., 2012; Li et al., 2018; Montagnat et al., 2014). Deep-ice anisotropic scattering has been observed in convergent ice flow zones, like our study area, in East Antarctica (Matsuoka et al., 2003, 2004). In those studies, anisotropic englacial reflections were attributed to stacked alternating layers of single-pole and vertical-girdle fabrics observed in the Dome F ice core. Such a model is consistent with our radar observations and ice core observations elsewhere in West Antarctica. A single maximum crystal orientation fabric distribution (i.e. 

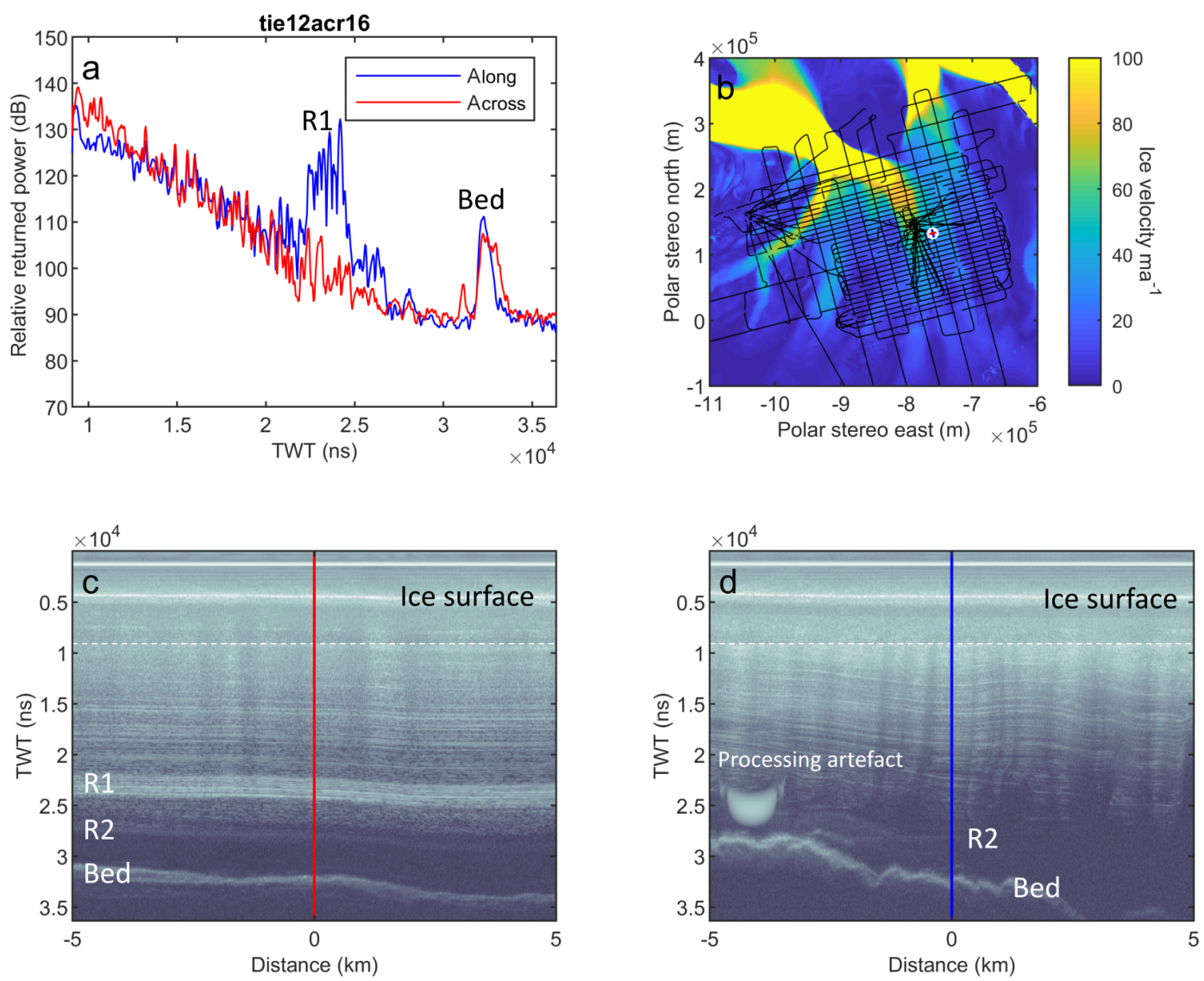

Figure 6. Example of the reflectivity of internal layering beneath Institute Ice Stream at crossover points: (a) relative returned power (dB) for 11 stacked 2D-SAR-processed traces ( $\sim 100 \mathrm{~m}$ of radar data) along (blue) and across (red) the ice flow. Reflection packages (R1) and the bed of the ice sheet are annotated. (b) Location of radar data crossover (filled white circle with location of the across- and along-flow directions), underlain by radar survey grid (thin black lines) and ice velocity (Mouginot et al., 2019), with a colour scale saturated at $100 \mathrm{~m} \mathrm{a}^{-1}$. (c) Radar data along the ice flow (spatial extent shown by blue line in b). Ice flow is left-to-right along the radargram. Crossover with across-ice flow radar data (d) is shown with a red vertical line. The blue profile in (a) is the returned power of the crossover trace stacked with five traces either side of this "vertical red line" crossover location. (d) Radar data across the ice flow (spatial extent shown by red line in b). Ice flow is into the radargram. Crossover with along-ice-flow radar data (c) is shown with the blue vertical line. The red profile in (a) is the returned power of the crossover trace stacked with five traces either side of this "vertical blue line" crossover location. In distinct contrast to (c), the reflection package R1 is not imaged in this data. Along- and across-flow radar data (c, d) were acquired with the same aircraft altitude and therefore the same range to the ice surface. This ensures that the geometry and anisotropy of the ice cannot be responsible for the pronounced anisotropy of the deep-ice unit. Dashed white lines in (c) and (d) define the boundary (200th vertical sample) between SAR-processed radar data (below line) and radar data that were not SAR processed (above line). Information on SAR processing of the dataset is available in Jeofry et al. (2018a).

with a fabric characterized by strong vertical $c$ axes), typical for simple shear, would not result in anisotropic scattering, as layer reflectivity would be the same in different survey orientation. A vertical girdle fabric on the other hand is consistent with anisotropic layer reflectivity, as crystals would have an oriented preferred fabric that would likely induce a backscatter response. Evidence for down-ice column evolution of crystal fabric (i.e. from isotropic to anisotropic, and then back to isotropic at depth) is observed in ice cores from West Antarctica (e.g. Gow and Williamson, 1976; Gow and Meese, 2007; Fitzpatrick et al., 2014), with anisotropic crystal fabrics typically associated with ice of the last glacial pe- riod. However, as stated above, an anisotropic crystal fabric (i.e. with a strong single vertical maxima) would not result in an anisotropic radar response, so these gradual down-core changes cannot be the explanation for R1. In the Byrd core, however, there is evidence for sharply alternating crystal fabrics (i.e. narrow cone to distributed cone and back again) associated with cloudy bands (1-60 mm thick) of glacial-age ice that incorporate tephra (Gow and Williamson, 1976; Horgan et al., 2011). Abrupt alternations in crystal fabric such as these are akin to those proposed as the cause of anisotropic radar scattering in East Antarctica (Fujita et al., 2003; Matsuoka et al., 2003, 2004). Assuming that the cloudy bands in 
the Byrd core represent the same stratigraphy as R1, then this is a plausible explanation for the radar reflection anisotropy of this layer. The anisotropy cannot be due to directional roughness of layer reflectivity, as the anisotropy is unique to specific layers (Figs. 6a and S1-S4). R2 is also a prominent and strong reflection (Figs. 2, 3, and 4), but unlike R1 it is not characterized by anisotropic reflectivity (Fig. 6). We consider R2 to represent a layer with a discretely high conductivity, similar to the bulk of internal layers in Antarctica (Siegert, 1999). The anomalously high reflectivity of R2 may represent a pronounced acidity spike, or multiple spikes, in the stratigraphy.

\subsection{Formation of the deep-ice unit}

The "freeze-on" hypothesis for the formation of basal ice (Bell et al., 2011) cannot explain the deep-ice unit and incorporated layers (i.e. R1 to the ice sheet bed) for four reasons: (1) unlike Greenland, West Antarctica lacks input of water from surface ablation processes, thus the water would need to be derived entirely from subglacial melt, and across the majority of the area covered by R1 and R2 the ice is typically thin (i.e. $<1.5 \mathrm{~km}$ ), slow-flowing (i.e. $<25 \mathrm{~m} \mathrm{a}^{-1}$ ), and likely frozen to the bed; (2) in the central IIS catchment, where the bed is wet, the ice is relatively fast-flowing, thus the basal ice observed there could not have formed by freeze-on as it would advect down-flow before a significant thickness of ice could develop (without unrealistically high rates of freezing) (cf. Dow et al., 2018); (3) IIS has a welldefined and efficient topographically-constrained subglacial drainage network without widespread stores of subglacial water to act as water sources (Wright and Siegert, 2012; Jeofry et al., 2018a, b); and (4) although during more extensive glacial conditions the hypothesized subglacial lakes in the upper catchment of IIS and MIS associated with thicker ice and a low gradient ice sheet surface slope (see Livingstone et al., 2013) could provide subglacial water for basal freeze on, we observe the deep-ice unit in locations far removed from potential subglacial meltwater pathways (e.g. Winter et al., 2015; Bingham et al., 2015) (Figs. 1 and 2). Proposed active subglacial lakes in the IIS-MIS catchment investigated with ice-penetrating radar demonstrate little evidence for significant ponding of subglacial water (Siegert et al., 2014, 2016), with no apparent connection to the englacial folds in these locations.

Given the consistent stratigraphic position of R1 and R2 in all areas of the IIS-MIS that they are found (e.g. Figs. 1 and 2 ), regardless of bed conditions and flow speeds, we conclude that the structures and lateral extent of the deep-ice structures must be the result of the deformation and localized folding of meteoric ice. Further, given the radar anisotropy observed, the most likely explanation for the folds is that they are caused by a combination of convergent ice flow and the distinct physical (i.e. varying crystal orientation fabric) and subsequently rheological properties of the band of ice associated with R1.

\subsection{Physical properties and rheology of the folds: modulation of ice flow}

The most prominent fold observed is consistently associated with the boundary of enhanced ice flow and the ice stream trunk surface flow stripe (Figs. 1c, 3a-b, d and 5).

This spatial correspondence between the fold and shear margin is remarkable and may suggest that the folding of the deep ice modulates the position of the shear margin and controls trunk flow. The fold may therefore play an important role in the ice dynamics of the IIS-MIS catchment. The simplest explanation is that the core of the fold contains higher viscosity material, be that ice and/or sediment, which is less conducive to deformation than adjacent ice. The highviscosity material resists ice flow, leading to (relatively) fast ice flow to one side and slower flow on the other, where up to four other folds are present. Evidence supporting the core of the primary fold being more resistant to flow exists in observations of ice surface "bumps" directly above the largest anticline in some across-flow survey lines.

The core of the most prominent anticline contains a consistently bright hand-shaped reflection at the bed that is several hundred metres high and wide (Figs. 3a, 3d, 4 and 5) and allows its unequivocal identification (Fig. 5). This reflection is observed below R2 in more than 15 across-flow lines and in the survey lines cutting obliquely across the ice stream trunk (Fig. 5). Along the flow, the feature is a set of bedconformable reflectors (Fig. 3c). Our interpretation of this reflection is that it represents sediment drawn up into fractures in the base of the ice sheet during compressional fold formation (Winter et al., 2019); such an inclusion of sediment would significantly alter the rheology of the core of the anticline. This may determine the position of the lateral margin of the tributary of enhanced ice flow, the different "compartments" of ice stream trunk flow, and the position of the IIS ice plain.

\subsection{The influence of climate history on ice sheet stratigraphy, structure, and rheology}

The radar reflections that characterize the IIS-MIS deep-ice unit have distinct signatures that are comparable to deepice reflections recorded beneath the central Greenland Ice Sheet where, because of strongly contrasting physical and rheological properties of glacial and interglacial ice, deep ice of Eemian age and older is folded, sheared, and overturned (NEEM community members, 2013; Bell et al., 2014; Bons et al., 2016; MacGregor et al., 2015). Similarly, it is possible that the varying reflection properties of the IIS-MIS deepice package are associated with boundaries or interfaces between ice accumulated during contrasting climatic periods (i.e. glacial or stadial and interglacial or interstadial periods). 
The last deglaciation in West Antarctica was characterized by a rapid increase in the rate of surface accumulation (WAIS Divide Project Members, 2013) and a 192-year period of acid deposition associated with major volcanic activity (Gow and Williamson, 1976; McConnell et al., 2017). A new radiostratigraphy across West Antarctica (Ashmore et al., 2020) enables us to infer the likely age of the deep-ice units in the IIS-MIS. The best "direct" constraint on the age of the deepice package is from the dated radar englacial layer tied to the Byrd ice core (Siegert and Payne, 2004; Ashmore et al., 2020). Linking the radar stratigraphy of the IIS-MIS catchment to the radar transect of Siegert and Payne (2004), where our 2010-2011 survey data intersect their profile (Ashmore et al., 2020), indicates that the transition between the upper undisrupted high-reflectivity ice and the lower deep-ice unit (i.e. R1) can be dated to approximately $16 \mathrm{ka}$. There are some potential uncertainties associated with this correlation (e.g. resolution of the Byrd ice core and the resolution, geolocation, and vertical and along-track sampling of the SPRI-NSFTUD RES data). However, assuming this correlation to be correct, the low-reflectivity zone between R1 and R2 is from the last glacial period, with the potential for even older ice in places. As glacial ice tends to be rheologically "softer" than interglacial ice, enhanced flow often occurs in such layers (Paterson 1991; Pettit et al., 2014; NEEM community members, 2013). The ice crystal fabric associated with R1 could be the product of differential shear associated with ice sheet physical properties produced by (i) the abrupt change in WAIS accumulation (WAIS Divide Project Members, 2013) and/or (ii) the volcanic deposit known as "Old Faithful" (Jacobel and Welch, 2005), both associated with the termination of the last glacial period in West Antarctica. R2 would then represent ice older (potentially significantly older) than the Last Glacial Maximum. The bifurcation of R2 into multiple layers (Fig. 2b) may be of note here; multiple tephras dating to the last glacial cycle (i.e. at 22.3, 32.4 and $44.8 \mathrm{ka}$ ) have recently been recorded in parts of West Antarctica (Iverson et al., 2017). Older widespread West Antarctic tephras from Marine Isotopic Stages 6 and 5 are also recognized in marine sediments from the continental shelf (Hillenbrand et al., 2008).

Englacial processes similar to those responsible for the formation of the deep-ice unit in the IIS-MIS catchment are likely to occur elsewhere in Antarctica. Radar data from the Siple Coast region record the presence of a major fold and upwarping of ice, for example (Siegert et al., 2004). The formation of this fold was originally ascribed to a Holocene ice flow reorganization, but formation through deformation and folding of deep ice of varying rheological properties by convergent ice flow is a viable explanation prior to ice flow direction change.

\section{Conclusions}

We have demonstrated the presence of an extensive package of deep-ice units beneath the Institute and Möller ice streams. At least one layer in the deep ice has physical properties (i.e. ice crystal orientation fabric and rheology) that are significantly different to the upper ice column. At the lateral boundary of the onset of enhanced ice flow of IIS, where ice flow is convergent, these deep-ice units have been heavily deformed. Deformation has led to the development of largescale englacial folds that may modulate ice stream position, structure, and dynamics. Due to the extensive spatial extent of the deep-ice unit and its vertical and horizontal variability in crystal fabric and rheology, such units have important implications for assumptions underlying our understanding of ice sheet tributary and trunk flow. Our results confirm that ice flow across the bulk of West Antarctica (and potentially other ice masses) is more complex than is currently incorporated within the set-up and application of many numerical ice sheet simulations used to determine ice dynamics and predict global sea level. As future ice flow models with greater computational power and grid resolution incorporate the effects of rheology on ice dynamics, they must ensure that they reflect internal ice sheet stratigraphy and deformation structures such as those reported here.

Data availability. SEG-Y files of the 2D-focused SARprocessed radar data are available from the UK Polar Data Centre https://data.bas.ac.uk/metadata.php?id=GB/ NERC/BAS/PDC/00937 (https://doi.org/10.5285/8a975b9ef18c-4c51-9bdb-b00b82da52b8, Siegert et al., 2017). Ice thickness picks for the IMAFI survey are available from the UK Polar Airborne Geophysics Data Portal https://legacy.bas.ac.uk/data/aerogeo/dataset/imafi/ (last access: 29 June 2020).

Supplement. The supplement related to this article is available online at: https://doi.org/10.5194/tc-14-2103-2020-supplement.

Author contributions. NR and MS wrote the paper. HC and NR processed the data. NR collected and analysed the data. MS was the principal investigator of the IMAFI project. All authors contributed to the final version of the manuscript.

Competing interests. The authors declare that they have no conflict of interest.

Acknowledgements. We thank the Institute and Möller ice stream Antarctic Funding Initiative (IMAFI) science and field team (Fausto Ferraccioli, Tom A. Jordan, Rob Bingham, David Rippin, Anne Le Brocq, Carl Robinson, Ian Potten, Doug Cochrane, Mark Oosterlander) and the British Antarctic Survey for their logistical assistance; 
John Woodward for discussions regarding entrainment of basal sediments; Rob Larter for information regarding Antarctic tephra deposits dating to the last glacial cycle; Tom M. Jordan for discussions on ice crystal fabric; and Rob Bingham, the TC editor Joe MacGregor, and four anonymous reviewers for helpful recommendations and comments on earlier versions of this manuscript. The IMAFI project was funded by UK NERC Antarctic Funding Initiative (grant no. NE/G013071/1). Aspects of this work were inspired and motivated by the Scientific Committee for Antarctic Research (SCAR) AntArchitecture community.

Financial support. This research has been supported by the Natural Environment Research Council (grant no. NE/G013071/1).

Review statement. This paper was edited by Joseph MacGregor and reviewed by two anonymous referees.

\section{References}

Ashmore, D. W., Bingham, R. G., Ross, N., Siegert, M. J., Jordan, T. A., and Mair, D. W. F.: Englacial Architecture and Age-Depth Constraints Across the West Antarctic Ice Sheet, Geophys. Res. Lett., 47, e2019GL086663, https://doi.org/10.1029/2019GL086663, 2020.

Bamber, J. L., Vaughan, D. G., and Joughin, I.: Widespread Complex Flow in the Interior of the Antarctic Ice Sheet, Science, 287, 1248-1250, https://doi.org/10.1126/science.287.5456.1248, 2000.

Bamber, J. L., Gomez-Dans, J. L., and Griggs, J. A.: Antarctic $1 \mathrm{~km}$ Digital Elevation Model (DEM) from Combined ERS-1 Radar and ICESat Laser Satellite Altimetry, Boulder, Colorado USA, National Snow and Ice Data Center, https://doi.org/10.5067/H0FQ1KL9NEKM, 2009.

Bell, R. E., Ferraccioli, F., Creyts, T. T., Braaten, D., Corr, H., Das, I., Damaske, D., Frearson, N., Jordan, T., Rose, K., Studinger, M., and Wolovick, M.: Widespread persistent thickening of the East Antarctic Ice Sheet by freezing from the base, Science, 331, 1592-1595, https://doi.org/10.1126/science.1200109, 2011.

Bell, R. E., Tinto, K., Das, I., Wolovick, M., Chu, W., Creyts, T. T., Frearson, N., Abdi, A., and Paden, J. D.: Deformation, warming and softening of Greenland's ice by refreezing meltwater, Nat. Geosci., 7, 497-502, https://doi.org/10.1038/ngeo2179, 2014.

Bentley, C. R.: Seismic evidence for moraine within the basal Antarctic ice sheet, in: Antarctic snow and ice studies II, edited by: Crary, A. P., American Geophysical Union, Washington, DC, 89-129, https://doi.org/10.1029/AR016p0089, 1971.

Bingham, R. G., Rippin, D. M., Karlsson, N. B., Corr, H. F. J., Ferraccioli, F., Jordan, T. A., Le Brocq, A. M., Rose, K. C., Ross, N., and Siegert, M. J.: Ice-flow structure and ice dynamic changes in the Weddell Sea sector of West Antarctica from radarimaged internal layering, J. Geophys. Res.-Earth, 120, 655-670, https://doi.org/10.1002/2014JF003291, 2015.

Bohlander, J. and Scambos, T.: Antarctic coastlines and grounding line derived from MODIS Mosaic of Antarctica (MOA)m Boulder, Colorado USA, National Snow and Ice Data Center, 2007.
Bons, P. D., Jansen, D., Mundel, F., Bauer, C. C., Binder, T., Eisen, O., Jessell, M. W., Llorens, M.-G., Steinbach, F., Steinhage, D., and Weikusat, I.: Converging flow and anisotrophy cause largescale folding in Greenland's ice sheet, Nat. Commun., 7, 11427, https://doi.org/10.1038/ncomms11427, 2016.

Conway, H., Catania, G., Raymond, C. F., Gades, A. M., Scambos, T. A., and Engelhardt, H.: Switch of flow direction in an Antarctic ice stream, Nature, 419, 465-467, https://doi.org/10.1038/nature01081, 2002.

Corr, H. F. J. and Vaughan, D. G.: A recent volcanic eruption beneath the West Antarctic ice sheet, Nat. Geosci., 1, 122-125, https://doi.org/10.1038/ngeo106, 2008.

Dow, C. F., Karlsson, N. B., and Werder, M. A.: Limited Impact of Subglacial Supercooling Freeze-on for Greenland Ice Sheet Stratigraphy, Geophys. Res. Lett., 45, 1481-1489, https://doi.org/10.1002/2017GL076251, 2018.

Drews, R., Eisen, O., Steinhage, D., Weikusat, I., Kipfstuhl, S., and Wilhelms, F.: Potential mechanisms for anisotropy in ice-penetrating radar data, J. Glaciol., 58, 613-624, https://doi.org/10.3189/2012JoG11J114, 2012.

Eisen, O., Hamann, I., Kipfstuhl, S., Steinhage, D., and Wilhelms, F.: Direct evidence for continuous radar reflector originating from changes in crystal-orientation fabric, The Cryosphere, 1, 1-10, https://doi.org/10.5194/tc-1-1-2007, 2007.

Ely, J. C. and Clark, C. D.: Flow-stripes and foliations of the Antarctic ice sheet, J. Maps, 12, 249-259, https://doi.org/10.1080/17445647.2015.1010617, 2016.

Fitzpatrick, J. J., Voigt, D. E., Fegyveresi, J. M., Stevens, N. T., Spencer, M. K., Cole-Dai, J., Alley, R. B., Jardine, G. E., Cravens, E. D., Wilen, L., A., Fudge, T. J., and McConnell, J. R.: Physical properties of the WAIS divide ice core, J. Glaciol., 60, 1181-1198, https://doi.org/10.3189/2014JoG14J100, 2014.

Fricker, H. A. and Padman, L.: Ice shelf grounding zone structure from ICESat laser altimetry, Geophys. Res. Lett., 33, L15502, https://doi.org/10.1029/2006GL026907, 2006.

Fujita, S., Maeno, H. Uratsuka, S., Furukawa, T., Mae, S., Fujii, Y., and Watanabe, O.: Nature of radio-echo layering in the Antarctic ice sheet detected by a twofrequency experiment, J. Geophys. Res., 104, 13013-13024, https://doi.org/10.1029/1999JB900034, 1999.

Fujita, S., Matsuoka, K., Maeno, H., and Furukawa, T.: Scattering of VHF radio waves from within an ice sheet containing the vertical-girdle-type ice fabric and anisotropic reflection boundaries, Ann. Glaciol., 37, 305316, https://doi.org/10.3189/172756403781815979, 2003.

Fujita, S., Maeno, H., and Matsuoka, K.: Radio-wave depolarization and scattering within ice sheets: a matrix-based model to link radar and ice-core measurements and its application, J. Glaciol., 52, 407-424, https://doi.org/10.3189/172756506781828548, 2006.

Glasser, N. F. and Gudmundsson, G. H.: Longitudinal surface structures (flowstripes) on Antarctic glaciers, The Cryosphere, 6, 383391, https://doi.org/10.5194/tc-6-383-2012, 2012.

Goldberg, M. L., Schroeder, D. M., Castelletti, D., Mantelli, E., Ross, N., and Siegert, M. J.: Automated detection and characterization of Antarctic basal units using radar sounding data: Demonstration in Institute Ice Stream, West Antarctica, Ann. Glaciol., 61, https://doi.org/10.1017/aog.2020.27, online first, 2020. 
Gow, A. J. and Meese D.: Physical properties, crystalline textures and c-axis fabrics of the Siple Dome (Antarctica) ice core, J. Glaciol., 53, 573-584, https://doi.org/10.3189/002214307784409252, 2007.

Gow, A. J. and Williamson, T.: Rheological implications of the internal structure and crystal fabrics of the West Antarctic Ice Sheet as revealed by deep core drilling at Byrd Station, Geol. Soc. Am. Bull., 12, 1665-1677, https://doi.org/10.1130/00167606(1976)87<1665:RIOTIS>2.0.CO;2, 1976.

Haran, T., Bohlander, J., Scambos, T., Painter, T., and Fahnestock, M.: 2005, updated 2019: MODIS Mosaic of Antarctica 2003-2004 (MOA2004) Image Map, Version 1. Boulder, Colorado USA, NSIDC: National Snow and Ice Data Center, https://doi.org/10.7265/N5ZK5DM5, 2005.

Harrison, C. H.: Radio echo sounding of horizontal layers in ice, J. Glaciol., 12, 383-397, https://doi.org/10.3189/S0022143000031804, 1973.

Hillenbrand, C.-D., Moreton, S. G., Caburlotto, A., Pudsey, C. J., Lucchi, R. G., Smellie, J. L., Benetti, S., Grobe, H., Hunt, J. B., and Larter, R. D.: Volcanic time-markers for Marine Isotopic Stages 6 and 5 in Southern Ocean sediments and Antarctic ice cores: implications for tephra correlations between palaeoclimatic records, Quaternary Sci. Rev., 27, 518-540, 2008.

Holschuh, N., Christianson, K., and Anandakrishnan, S.: Power loss in dipping internal reflectors, imaged using ice-penetrating radar, Ann. Glaciol., 55, 49-56, https://doi.org/10.3189/2014AoG67A005, 2014.

Horgan, H. J., Anandakrishnan, S., Alley, R. B., Burkett, P. G., and Peters, L. E.: Englacial seismic reflectivity: imaging crystalorientation fabric in West Antarctica, J. Glaciol., 57, 639-650, https://doi.org/10.3189/002214311797409686, 2011.

Hudleston, P. J.: Structures and fabrics in glacial ice: A review, J. Struct. Geol., 81, 1-27, https://doi.org/10.1016/j.jsg.2015.09.003, 2015.

Iverson, N. A., Lieb-Lappen, R., Dunbar, N. W., Obbard, R., Kim, E., and Golden, E.: The first physical evidence of subglacial volcanism under the West Antarctic Ice Sheet, Sci. Rep., 7, 11457, https://doi.org/10.1038/s41598-017-11515-3, 2017.

Jacobel, R. W. and Welch, B. C.: A time marker at $17.5 \mathrm{kyr}$ BP detected throughout West Antarctica, Ann. Glaciol., 41, 47-51, https://doi.org/10.3189/172756405781813348, 2005.

Jacobel, R. W., Gades, A. M., Gottschling, D. L., Hodge, S. M., and Wright, D. L.: Interpretation of radar-detected internal layer folding in West Antarctic ice streams, J. Glaciol., 39, 528-537, https://doi.org/10.3189/S0022143000016427, 1993.

Jeofry, H., Ross, N., Corr, H. F. J., Li, J., Morlighem, M., Gogineni, P., and Siegert, M. J.: A new bed elevation model for the Weddell Sea sector of the West Antarctic Ice Sheet, Earth Syst. Sci. Data, 10, 711-725, https://doi.org/10.5194/essd-10-711-2018, 2018a.

Jeofry, H., Ross, N., Le Brocq, A., Graham, A., Li, J., Gogineni, P., Morlighem, M., Jordan, T., and Siegert, M. J.: Hard rock landforms generate $130 \mathrm{~km}$ ice shelf channels through water focusing in basal corrugations, Nat. Commun., 9, 4576, https://doi.org/10.1038/s41467-018-06679-z, 2018b.

Jezek, K. C., Curlander, J. C., Carsey, F., Wales, C., and Barry, R. G.: RAMP AMM-1 SAR Image Mosaic of Antarctica, Version 2. Boulder, Colorado USA, NSIDC: National Snow and Ice Data Center, https://doi.org/10.5067/8AF4ZRPULS4H, 2013.
Jordan, T. A., Ferraccioli, F., Ross, N., Corr, H. F. J., Leat, P. T., Bingham, R. G., Rippin, D. M., Le Brocq, A., and Siegert, M. J.: Inland extent of the Weddell Sea Rift imaged by new aerogeophysical data, Tectonophysics, 585, 137-160, https://doi.org/10.1016/j.tecto.2012.09.010, 2013.

Joughin, I., Gray, L., Bindschadler, R., Price, S., Morse, D., Hulbe, C., Mattar, K., and Werner, C.: Tributaries of West Antarctic Ice Streams Revealed by RADARSAT Interferometry, Science, 286, 283-286, https://doi.org/10.1126/science.286.5438.283, 1999.

Karlsson, N. B., Rippin, D. M., Vaughan, D. G., and Corr, H. F. J.: The internal layering of Pine Island Glacier, West Antarctica, from airborne radar-sounding data, Ann. Glaciol., 50, 141-146, https://doi.org/10.3189/S0260305500250660, 2009.

Leysinger Vieli, G. J.-M. C., Martín, C., Hindmarsh, R. C. A., and Lüthi, M. P.: Freeze-on generates complex ice-sheet stratigraphy, Nat. Commun., 9, 4669, https://doi.org/10.1038/s41467018-07083-3, 2018

Li, J., Vélez González, J. A., Leuschen, C., Harish, A., Gogineni, P., Montagnat, M., Weikusat, I., Rodriguez-Morales, F., and Paden, J.: Multi-channel and multi-polarization radar measurements around the NEEM site, The Cryosphere, 12, 2689-2705, https://doi.org/10.5194/tc-12-2689-2018, 2018.

Livingstone, S. J., Clark, C. D., Woodward, J., and Kingslake, J.: Potential subglacial lake locations and meltwater drainage pathways beneath the Antarctic and Greenland ice sheets, The Cryosphere, 7, 1721-1740, https://doi.org/10.5194/tc-7-17212013, 2013.

MacGregor, J. A., Fahnestock, M. A., Catania, G. A., Paden, J. D., Gogineni, S. P., Young, S. K., Rybarski, S. C., Mabrey, A. N., Wagman, B. M., and Morlighem, M.: Radiostratigraphy and age structure of the Greenland Ice Sheet, J. Geophys. Res.-Earth, 120, 212-241, https://doi.org/10.1002/2014JF003215, 2015.

Matsuoka, K., Furukawa, T., Fujita, S., Maeno, H., Uratsuka, S., Naruse, R., and Watanabe, O.: Crystal orientation fabrics within the Antarctic ice sheet revealed by a multipolarization plane and dual-frequency radar survey, J. Geophys. Res.-Earth, 108, 2499, https://doi.org/10.1029/2003JB002425, 2003.

Matsuoka, K., Uratsuka, S., Fujita, S., and Nishio, F.: Ice-flowinduced scattering zone within the Antarctic ice sheet revealed by high-frequency airborne radar, J. Glaciol., 50, 382-388, https://doi.org/10.3189/172756504781829891, 2004.

McConnell, J. R., Burke, A., Dunbar, N. W., Köhler, P., Thomas, J. L., Arienzo, M. M., Chellman, N. J., Maselli, O. J., Sigl, M., Adkins, J. F., Baggenstos, D., Burkhart, J. F., Brook, E. J., Buizert, C., Cole-Dai, J., Fudge, T. J., Knorr, G., Graf, H.-F., Grieman, M. M., Iverson, N., McGwire, K. C., Mulvaney, R., Paris, G., Rhodes, R. H., Saltzman, E. S., Severinghaus, J. P., Steffensen, J. P., Taylor, K. C., and Winckler, G.: Synchronous volcanic eruptions and abrupt climate change $17.7 \mathrm{ka}$ plausibly linked by stratospheric ozone depletion, P. Natl. Acad. Sci. USA, 114, 10035-10040, https://doi.org/10.1073/pnas.1705595114, 2017.

Mouginot, J., Rignot, E., and Scheuchl, B.: ContinentWide, Interferometric SAR Phase, Mapping of Antarctic Ice Velocity, Geophys. Res. Lett., 46, 9710-9718, https://doi.org/10.1029/2019GL083826, 2019.

Montagnat, M., Azuma, N., Dahl-Jensen, D., Eichler, J., Fujita, S., Gillet-Chaulet, F., Kipfstuhl, S., Samyn, D., Svensson, A., and Weikusat, I.: Fabric along the NEEM ice core, Greenland, and its 
comparison with GRIP and NGRIP ice cores, The Cryosphere, 8 , 1129-1138, https://doi.org/10.5194/tc-8-1129-2014, 2014.

NEEM community members: Eemian interglacial reconstructed from a Greenland folded ice core, Nature, 493, 489-494, https://doi.org/10.1038/nature11789, 2013.

$\mathrm{Ng}$, F. and Conway, H.: Fast-flow signature in the stagnated Kamb Ice Stream, West Antarctica, Geology, 32, 481-484, https://doi.org/10.1130/G20317.1, 2004.

Paren, J. G. and Robin, G. de Q., Internal Reflections in Polar Ice Sheets, J. Glaciol., 14, 251-259, https://doi.org/10.3189/S0022143000021730, 1975.

Paterson, W. S. B.: Why ice-age ice is sometimes "soft", Cold Reg. Sci. Technol., 20, 75-98, https://doi.org/10.1016/0165232X(91)90058-O, 1991.

Pettit, E. C., Whorton, E. N., Waddington, E. D., and Sletten, R. S.: Influence of debris-rich basal ice on flow of a polar glacier, J. Glaciol., 60, 989-1006, https://doi.org/10.3189/2014JoG13J161, 2014.

Rignot, E., Mouginot, J., and Scheuchl, B.: Antarctic grounding line mapping from differential satellite radar interferometry, Geophys. Res. Lett., 38, L10504, https://doi.org/10.1029/2011GL047109, 2011.

Rignot, E., Mouginot, J., and Scheuchl, B.: MEaSUREs InSARBased Antarctica Ice Velocity Map, Version 2, Boulder, Colorado USA, NASA National Snow and Ice Data Center Distributed Active Archive Center, https://doi.org/10.5067/D7GK8F5J8M8R, 2017.

Robin, G. de Q., and Millar, D. H. M.: Flow of ice sheets in the vicinity of subglacial peaks, Ann. Glaciol., 3, 290-294, https://doi.org/10.3189/S0260305500002949, 1982.

Rose, K. C., Ross, N., Jordan, T. A., Bingham, R. G., Corr, H. F. J., Ferraccioli, F., Le Brocq, A. M., Rippin, D. M., and Siegert, M. J.: Ancient pre-glacial erosion surfaces preserved beneath the West Antarctic Ice Sheet, Earth Surf. Dynam., 3, 139-152, https://doi.org/10.5194/esurf-3-139-2015, 2015.

Ross, N., Bingham, R. G., Corr, H. F. J., Ferraccioli, F., Jordan, T. A., Le Brocq, A., Rippin, D. M., Young, D., Blankenship, D. D., and Siegert, M. J.: Steep reverse bed slope at the grounding line of the Weddell Sea sector in West Antarctica, Nat. Geosci., 5, 393-396, https://doi.org/10.1038/ngeo1468, 2012.

Ross, N., Jordan, T. A., Bingham, R. G., Corr, H. F. J., Ferraccioli, F., Le Brocq, A., Rippin, D. M., Wright, A. P., and Siegert, M. J.: The Ellsworth Subglacial Highlands: inception and retreat of the West Antarctic Ice Sheet, Geol. Soc. Am. Bull., 126, 3-15, https://doi.org/10.1130/B30794.1, 2014.

Siegert, M. J.: On the origin, nature and uses of Antarctic icesheet radio-echo layering, Prog. Phys. Geogr., 23, 159-179, https://doi.org/10.1177/030913339902300201, 1999.

Siegert, M. J. and Fujita, S.: Internal ice-sheet radar layer profiles and their relation to reflection mechanisms between Dome C and the Trans Antarctic Mountains, J. Glaciol., 47, 205-212, https://doi.org/10.3189/172756501781832205, 2001.

Siegert, M. J. and Payne, A. J.: Past rates of accumulation in central West Antarctica, Geophys. Res. Lett., 31, L12403, https://doi.org/10.1029/2004GL020290, 2004.

Siegert, M. J., Welch, B., Morse, D., Vieli, A., Blankenship, D. D., Joughin, I., King, E. C., Leysinger Vieli, G. J.M. C., Payne, A. J., and Jacobel, R.: Ice flow direction change in interior West Antarctica, Science, 305, 1948-1951, https://doi.org/10.1126/science.1101072, 2004.

Siegert, M. J., Ross, N., Corr, H., Smith, B., Jordan, T., Bingham, R. G., Ferraccioli, F., Rippin, D. M., and Le Brocq, A.: Boundary conditions of an active West Antarctic subglacial lake: implications for storage of water beneath the ice sheet, The Cryosphere, 8, 15-24, https://doi.org/10.5194/tc-8-15-2014, 2014.

Siegert, M. J., Ross, N., Li, J. Schroeder, D. M., Rippin, D., Ashmore, D., Bingham, R., and Gogineni, P.: Subglacial controls on the flow of the Institute Ice Stream, West Antarctica, Ann. Glaciol., 57, 19-24, https://doi.org/10.1017/aog.2016.17, 2016.

Siegert, M., Jeofry, H., Corr, H., Ross, N., Jordan, T., Ferraccioli, F., Bingham, R., Le Brocq, A., Rippin, D., and Robinson, C.: Synthetic-aperture radar (SAR) processed airborne radio-echo sounding data from the Institute and Moller ice streams, West Antarctica, 2010-11, Cambridge, Polar Data Centre, Natural Environment Research Council, UK, 16.2GB, https://doi.org/10.5285/8a975b9e-f18c-4c519bdb-b00b82da52b8, 2017.

WAIS Divide Project Members: Onset of deglacial warming in West Antarctica driven by local orbital forcing, Nature, 500, 440-444, https://doi.org/10.1038/nature12376, 2013.

Wang, B., Sun, B., Ferroccioli, F., Martin, C., Steinhage, D., Cui, X., and Siegert, M. J.: Summit of the East Antarctic Ice Sheet underlain by extensive thick ice-crystal fabric layers formed by glacial-interglacial environmental change, in: Exploration of Subsurface Antarctica: Uncovering Past Changes and Modern Processes, edited by: Siegert, M. J., Jamieson, S. S. R., and White, D. A., Geological Society, London, Special Publication 461, 131-143, https://doi.org/10.1144/SP461.1, 2018.

Winter, K., Woodward, J., Ross, N., Dunning, S. A., Bingham, R. G., and Corr, H. F. J., and Siegert, M. J.: Airborne radar evidence for tributary flow switching in the Institute Ice Stream, West Antarctica: implications for ice sheet configuration and dynamics, J. Geophys. Res.-Earth, 120, 1611-1625, https://doi.org/10.1002/2015JF003518, 2015.

Winter, K., Woodward, J. Ross, N., Dunning, S. A., Hein, A. S., Westoby, M. J., Culberg, R., Marrero, S. M., Schroeder, D. M., Sugden, D. E., and Siegert, M. J.: Radar-Detected Englacial Debris in the West Antarctic Ice Sheet, Geophys. Res. Lett., 46, 10454-10462, https://doi.org/10.1029/2019GL084012, 2019.

Wolovick, M. J. and Creyts, T. T.: Overturned folds in ice sheets: Insights from a kinematic model of traveling sticky patches and comparisons with observations, J. Geophys. Res.-Earth, 121, 1065-1083, https://doi.org/10.1002/2015JF003698, 2016.

Wolovick, M. J., Creyts, T. T., Buck, W. R., and Bell, R. E.: Traveling slippery patches produce thickness-scale folds in ice sheets, Geophys. Res. Lett., 41, 8895-8901, https://doi.org/10.1002/2014GL062248, 2014.

Wright, A. and Siegert, M.: A fourth inventory of Antarctic subglacial lakes, Antarct. Sci., 24, 659-664, https://doi.org/10.1017/S095410201200048X, 2012.

Wrona, T., Wolovick, M., Ferraccioli, F., Corr, H., Jordan, T., and Siegert, M. J.: Position and variability of complex structures in the central East Antarctic Ice Sheet, in: Exploration of Subsurface Antarctica: Uncovering Past Changes and Modern Processes, edited by: Siegert, M. J., Jamieson, S. S. R., and White, D. A., Geological Society, London, Special Publication 461, 113129, https://doi.org/10.1144/SP461.12, 2018. 